\title{
Analisis Penggunaan Alat Mesin Pertanian Berbasis Traktor Tangan pada Kegiatan Perawatan Budidaya Tebu
}

\author{
Analysis Hand Tractor Based Mechanization in Sugarcane Cultivation \\ Deddy Purwantoro ${ }^{1 *}$, ${\text { Trikuntari Dianpratiwi }{ }^{2} \text {, Sri Markumningsih }}^{3}$ \\ ${ }^{1}$ Pusat Penelitian Perkebunan Gula Indonesia, Kebun Percobaan Jatiroto \\ Jl. Jatiroto No. A-10 Kecamatan Jatiroto, Lumajang, Indonesia \\ ${ }^{2}$ Pusat Penelitian Perkebunan Gula Indonesia, Jl. Pahlawan No. 25 Pasuruan, Indonesia \\ ${ }^{3}$ Departemen Teknik Pertanian dan Biosistem, Fakultas Teknologi Pertanian, Universitas Gadjah Mada, \\ Jl. Flora No. 1, Bulaksumur, Yogyakarta 55281, Indonesia \\ *Email: deddypur@p3gi.co.id
}

Tanggal submisi: 9 September 2017; Tanggal penerimaan: 31 Agustus 2018

\begin{abstract}
ABSTRAK
Jawa berkontribusi $63,7 \%$ terhadap produksi gula nasional, 55,6\% diproduksi oleh petani, dengan luas tanaman tebu 312.973 ha (65,6\% dari luas tanaman tebu di Indonesia). Di Jawa, mulai terjadi kelangkaan tenaga kerja untuk perawatan tebu, maka diperlukan alat mesin pertanian (alsintan). Masalahnya, ukuran alat/mesin tidak sesuai dengan luas lahan, suku cadang terbatas dan pengelolaan tidak optimal. Penelitian ini bertujuan untuk menghitung biaya penggunaan alsintan berbasis traktor tangan pada perawatan tanaman tebu sampai dengan umur 6 bulan. Penelitian dilakukan di Comal, Jawa Tengah pada tanah alluvial $8 \mathrm{mdpl}$, dan di Pasuruan, Jawa Timur pada tanah alluvial $10 \mathrm{mdpl}$. Setiap lokasi diambil 2 plot/petak kebun, dikerjakan dengan alsintan dan manual 3 ulangan masing-masing 0,1 ha diamati parametere agroteknis yaitu perkecambahan, jumlah batang, rumpun, tinggi tebu dan diameter batang serta parameter biaya penggunaan alsintan. Hasil kajian agroteknis dengan t-test taraf 0,05 menunjukkan dari parameter yang diamati tidak terdapat beda nyata. Selain itu penggunaan paket alsintan pemupukan, bumbun dan gulud di Pasuruan mampu menggantikan tenaga kerja manual 6 HOK, 12 HOK, dan 20 HOK pada setiap kegiatan budidaya tersebut, dengan traktor bekerja 7 jam/hari. Sedangkan di Comal alsintan dengan spesifikasi seperti yang digunakan dalam kajian ini mampu mensubstitusi tenaga kerja pemupukan $9 \mathrm{HOK}$, pembumbunan $16 \mathrm{HOK}$, pengguludan $20 \mathrm{HOK}$. Hasil analisis biaya alsintan $35,54 \%$ lebih rendah bandingkan secara manual. Pada penelitian ini dapat disimpulkan bahwa paket alsintan mampu menggantikan tenaga kerja manual pada kegiatan perawatan.
\end{abstract}

Kata kunci: Alat mesin pertanian; agroteknis; biaya; traktor tangan; tebu

\section{ABSTRACT}

Java contributes $63.7 \%$ of national sugar production, in which $55.6 \%$ is produced by the farmer from 312,973 ha of sugarcane area (65.6\% of Indonesia's cane crop area). Farm labor in Java was very limited in the past two decades, so was needed mechanization. Howeveer, the size of agricultural machines were not accordance with the size of land, the limited of spares, and was not optimally managed. This research aimed to calculate operational cost of farm machinery (hand tractor) on the cane cultivation activities up to 6-month cane growth period. This study was carried out at Comal, Center of Java at alluvial land $8 \mathrm{mdpl}$ and at Pasuruan, East Java at alluvial $10 \mathrm{mdpl}$. From each location, 2 plots of 0.1 ha were observed. The treatments were manual and machine cultivation with 3 replications. The observed agrotechnical parameters were the bud emergence, number of stalk, clump, stalk height and diameter, and operational cost of using machinery. The agrotechnical result using t-test (95\% confidence rate) showed no significance among treatments. Other results revealed that using machinery 
for fertilizing, soil heaping up, and soil moving (gulud) in Pasuruan can substitute manual daily worker (HOK) for $6 \mathrm{HOK}, 12$ HOK and 20 HOK, respectively, using tractor by 7 hours/day. Meanwhile in Comal, using machinery for fertilizing, soil heaping up, and soil hilling up (gulud) can substitute manual daily worker (HOK) for 9 HOK, 16 HOK, and $20 \mathrm{HOK}$, respectively. The cost analysis indicated the $35.54 \%$ reduction of using machinery compared to the manual expense. This study revealed that the machinery could substitute the manual worker for cane cultivation.

Keywords: Agricultural machines; agrotechnical, cost; hand-tractor; sugarcane

\section{PENDAHULUAN}

Luasan pertanaman tebu seluruh Indonesia mencapai 477.123 ha dan sebagian besar berada di Jawa (312.973 ha). Direktorat Jenderal Perkebunan (2015) menyatakan bahwa $63,7 \%$ produksi gula nasional diproduksi di Jawa dan $55,6 \%$ diproduksi oleh petani (tebu rakyat) di Jawa. Program Swasembada Gula Nasional (PSGN) bertujuan untuk memenuhi gula nasional secara keseluruhan baik untuk konsumsi langsung maupun industri. Sasaran produksi gula yang dicanangkan untuk tahun 2014 adalah sebesar 5,7 juta ton, tetapi pada kenyataannya produksi gula nasional pada tahun 2014 hanya sekitar 2,58 juta ton (P3GI, 2014) yang berarti masih terdapat kekurangan produksi gula sebesar 3,15 juta ton. Salah satu penyebab tidak tercapainya target produksi ini adalah ketersediaan tenaga kerja, sedangkan yang lain diantaranya varietas, teknik budidaya, ketersediaan air, curah hujan dan efisiensi pabrik gula.

Areal perkebunan yang luas membutuhkan tenaga kerja dalam jumlah besar, terutama pada saat tanam dan panen. Untuk menghindari kemungkinan kurang tersedianya tenaga kerja serta meningkatkan efisiensi maka diterapkan mekanisasi (Ekoprianto, 1985). Penelitian lain menunjukkan bahwa pada kegiatan tebang tebu menunjukkan perbedaan yang signifikan terhadap hasil tebangan, dimana penebangan secara mekanis lebih tinggi dibanding manual (Ahmed dkk., 2015). Saat ini di Jawa mulai terasa kelangkaan tenaga kerja di bidang on farm yang berdampak pada upah tenaga kerja yang semakin meningkat dan biaya produksi yang tinggi. Kelangkaan dan mutu tenaga kerja yang rendah mengakibatkan sasaran pekerjaan kebun (jumlah, kualitas, dan ketepatan waktu) yang telah ditetapkan tidak dapat dicapai. Pada keadaan yang demikian produktivitas yang tinggi susah didapat. Penggunaan tenaga mekanis dimaksudkan untuk mengisi kekosongan atau kekurangan tenaga kerja sehingga tidak terjadi keterlambatan kegiatan budidaya tebu dan penurunan produksi gula (Kartohadikoesoemo, 1965).

Pada kenyataannya, selama ini penggunaan alat dan mesin budidaya tebu masih mengalami berbagai kendala, diantaranya tidak sesuainya ukuran alat/mesin dengan kondisi pengoperasian di lahan, suku cadang yang tersedia sangat terbatas dan pengelolaannya belum baik (Pramudya, 1989). Dengan demikian perlu diketahui kesesuaian alat mesin pertanian terhadap lahan yang akan dikerjakan, sehingga penggunaan alsintan tidak menimbulkan permasalahan baru pada lahan tersebut. Menurut Cheong dkk. (2009) areal tebu di Mauritius yang ditebang dengan alat mesin tebang berukuran besar mengakibatkan masalah tingkat infiltrasi yang buruk, yang disebabkan oleh pemadatan tanah dan akan mempengaruhi produksi tebu. Penggunaan traktor tangan pada budidaya tebu saat ini sebatas pengembangan alat kepras tebu (Syafrindi dkk., 2015), sedangkan alsintan pada kegiatan perawatan tebu belum pernah dipublikasikan. Pada lahan dengan petakan yang sempit juga memerlukan pemilihan alsintan yang tepat, agar alsintan dapat bekerja dengan kapasitas kerja tinggi dan lebih efisien dibandingan dengan tenaga manual yang mulai langka.

Permasalan lain di sebagian besar penanaman tebu rakyat adalah pada lahan yang sempit (kurang dari $0,5 \mathrm{ha}$ ) dan adanya pembatas berupa pematang, yang di tempat tertentu sangat ditabukan untuk dibongkar atau rusak karena penggunaan alsintan. Kepemilikan lahan sempit ini dikuatkan dengan data petak kebun di wilayah PTPN X (PERSERO) Jawa Timur yang luasnya kurang dari 1 ha adalah 65\%, antara $1-2,5$ ha adalah $24 \%$ dan diatas 2,5 ha adalah $11 \%$ dari total arealnya (P3GI, 2015). Informasi ini merupakan representasi kondisi luas petak lahan tebu di Jawa pada umumnya.

Menurut Rachmat (1992) pengembangan mekanisasi tebu masih diperlukan terutama penciptaan teknologi seperti rancang bangun alat mekanis. Tujuan dari penelitian ini adalah mengkaji penggunaan paket alsintan budidaya di lahan dengan petakan sempit dari segi aspek agroteknis dan biaya pada tanaman tebu sampai dengan umur 6 bulan. Hasil penelitian ini dapat digunakan sebagai bahan referensi untuk penyusunan kebijakan stakeholder terkait industri gula untuk mengatasi permasalahan kelangkaan tenaga kerja pada lahan tebu dengan petakan sempit. 


\section{METODE PENELITIAN}

\section{Alat}

Alsintan yang digunakan dalam penelitian ini adalah traktor tangan merek Kubota Tipe Rotary $12 \mathrm{HP}$, dilengkapi dengan aplikator pupuk, alat bumbun, dan alat gulud dengan spesifikasi ditunjukkan pada Tabel 1 dan Tabel 2. Visual peralatan disajikan pada Gamhar 1

\section{Pelaksanaan Penelitian}

Penelitian ini dilakukan di dua lokasi. Pertama, di Kebun Percobaan P3GI Comal, Jawa Tengah pada $6^{\circ} 55^{\prime} 42.50^{\prime \prime}$ LS dan 109³3'27.70" BT dengan jenis tanah alluvial dengan ketinggian tempat 8 meter di atas permukaan laut (mdpl). Lokasi kedua, Kebun Percobaan P3GI Pasuruan, Jawa Timur pada 7०40'4.78" LS dan $112^{\circ} 54^{\prime} 47.38^{\prime \prime}$ BT dengan jenis tanah alluvial dengan ketinggian tempat $10 \mathrm{mdpl}$. Pada setiap lokasi Kebun terdiri dari 2 plot/petak kebun yaitu perlakukan alsintan dan manual dengan masing-masing 3 ulangan seluas 0,1 ha.

Pengolahan tanah dilakukan dengan menggunakan traktor $110 \mathrm{HP}$, implemen disk plow serta furrower. Panjang juring dibuat sepanjang $10 \mathrm{~m}$, lebar got 0,5 $\mathrm{m}$ dan lebar baris juringan (Pusat ke Pusat/PKP) 1,35 $\mathrm{m}$. Kegiatan tanam tebu secara manual dilakukan pada awal Mei 2015 (5A) dan ditetapkan PSJT 941 karena sesuai dengan rekomendasi penataan varietas.

Pemupukan dilakukan secara manual dan mekanis (bersamaan dengan pengolahan tanah dengan traktor tangan). Dosis pupuk yang digunakan adalah pupuk Nitrogen sebanyak $6 \mathrm{ku} / \mathrm{ha}$ dan pupuk majemuk (NPK) sebesar $4 \mathrm{ku} / \mathrm{ha}$. Pendangiran, bumbun dan gulud dilakukan secara manual menggunakan garpu/lempak dan menggunakan disk ridger dan chisel ditarik dengan hand traktor. Masa tanam, varietas, pupuk serta PKP pada lahan dengan alsintan maupun manual adalah sama.

Pengumpulan data pada kegiatan agroteknis adalah dengan mencatat waktu kerja traktor dengan stopwatch dalam mengerjakan setiap tahapan kegiatan perawatan tebu pada setiap plot sampel. Selain itu, diamati juga parameter agronomis yaitu perkecambahan, jumlah batang, jumlah rumpun, tinggi batang dan diameter batang. Data parameter ekonomi adalah upah operator traktor, sewa alsintan, biaya bahan bakar (solar) serta upah tenaga kerja manual.

\section{Metode Analisan dan Pengujian Data}

\section{Kajian Agroteknis}

Pengamatan aspek agroteknis dilakukan pada kegiatan mekanis pemupukan, pembubunan dan pengguludan. Pada kegiatan pengolahan tanah tidak dilakukan pengujian alsintan, karena keduanya diolah secara mekanis. Kapasitas kerja traktor menunjukkan kemampuan traktor menyelesaikan suatu pekerjaan pada luas lahan per satu satuan waktu. Kapasitas kerja teoritis alsintan pada kegiatan pemupukan, pembumbunan dan pengguludan dapat dirumuskan seperti pada Persamaan 1.

$$
K t=W t \times V t \times 10^{-1}
$$

Dimana:

Kt : Kapasitas kerja teoritis (ha/jam)

Wt : Lebar kerja teoritis $(\mathrm{m})$

Vt : Kecepatan kerja teoritis $(\mathrm{km} / \mathrm{jam})$

Kapasitas kerja aktual adalah kemampuan kerja alsintan berdasarkan luas total pada waktu total yang digunakan. Kapasitas kerja aktual alsintan pada kegiatan pemupukan, pembubunan, dan pengguludan dapat dirumuskan pada Persamaan 2.

$$
K a=\frac{A}{t}
$$

Dimana:

$\begin{array}{ll}\text { Ka } & \text { : Kapasitas kerja aktual (ha/jam) } \\ \text { A } & \text { Luas lahan terkerjakan (ha) } \\ \text { t } & \text { : Waktu yang digunakan (jam) }\end{array}$

Efisiensi kerja lapang adalah perbandingan antara kapasitas kerja aktual dengan kapasitas kerja teoritis dalam persen (\%). Persamaan 3 digunakan untuk mengetahui efisiensi kerja lapang.

$$
E=\frac{\kappa u}{K t}
$$

Dimana :

$$
\begin{array}{ll}
\mathrm{E} & \text { : Efisiensi kerja lapang (\%) } \\
\mathrm{Ka} & \text { : Kapasitas kerja aktual (ha/jam) } \\
\mathrm{Kt} & \text { : Kapasitas kerja teoritis (ha/jam) }
\end{array}
$$

Rasio substitusi tenaga merupakan perbandingan kapasitas kerja aktual alsintan dengan kapasitas kerja aktual tenaga manual. Rasio substitusi dapat dirumuskan pada Persamaan 4.

$$
\text { Rasio }=\frac{K a \cdot A l}{\text { Ka.Man }}
$$

Dimana:

R : Rasio substitusi tenaga (orang)

Ka.Al : Kapasitas kerja aktual alsintan (ha/hari)

Ka.Man : Kapasitas kerja manual (ha/hari.orang)

Parameter agroteknis adalah persentase perkecambahan, jumlah batang, jumlah rumpun, diameter batang, dan tinggi tanaman. Parameter tersebut dianalisis secara statistik (t-test) dengan 
aplikasi Microsoft Excel 2007 untuk mengetahui tingkat signifikansi perlakuan alsintan.

\section{Kajian Biaya}

Kajian biaya dilakukan untuk mengetahui rasio kerugian dan keuntungan dengan cara membandingkan biaya yang digunakan untuk aplikasi alsintan dengan biaya tenaga kerja secara manual. Perhitunganperhitungan biaya penggunaan alsintan menggunakan asumsi kerja borongan yang berlaku saat tahun penelitian. Sehingga diketahui ekivalensi jumlah tenaga kerja (HOK) pada setiap tahap pekerjaan kebun. Sedangkan perhitungan biaya budidaya manual sesuai dengan sistem kerja baku yang dilakukan petani tebu setempat (standar biaya kebun lokasi). Dari analisis yang dilakukan diperoleh informasi keekonomian (kerugian atau keuntungan) atau $\mathrm{B} / \mathrm{C}$ rasio penggunaan paket alsintan yang sesuai untuk budidaya tebu di lahan sempit yang dapat mensubtitusi kekurangan tenaga kerja.

\section{HASIL DAN PEMBAHASAN}

\section{Agroteknis}

Hasil penelitian terdiri dari tiga hal yaitu: kinerja teknis paket alsintan, keragaan agronomi tebu aplikasi, dan keekonomian. Dengan demikian dapat diketahui kapasitas dan efektifitas penggunaan paket alsintan pada kegiatan pemupukan, pembumbunan, dan pengguludan pada tanaman tebu. Hasil analisa kapasitas lapang paket alsintan dibandingkan dengan tenaga kerja manual ditampilkan pada Tabel 3.

Pada Tabel 3 kegiatan aplikasi paket alsintan di Kebun Pasuruan alsintan mampu menggantikan tenaga kerja manual sebanyak $6 \mathrm{HOK}, 12 \mathrm{HOK}$ dan 20 HOK pada kegiatan pemupukan, pembumbunan, dan pengguludan. Kegiatan pemeliharaan tebu secara mekanis di Kebun Comal mampu mensubstitusi tenaga
Tabel 4. Keragaan agronomis tebu umur 6 bulan di Kebun Comal dan Pasuruan

\begin{tabular}{lcccc}
\hline \multirow{2}{*}{ Keragaan agronomis } & \multicolumn{2}{c}{ Comal } & \multicolumn{2}{c}{ Pasuruan } \\
\cline { 2 - 5 } & Mekanis & Manual & Mekanis & Manual \\
\hline Perkecambahan (\%) & 76,89 & 76,97 & 74,82 & 72,92 \\
Jumlah batang & 89,97 & 87,28 & 112,79 & 112,36 \\
Jumlah rumpun & 27,67 & 26,95 & 25,54 & 25,51 \\
Tinggi batang (cm) & 87,54 & 84,35 & 110,33 & 145,00 \\
Diameter batang (mm) & 23,06 & 23,85 & 25,67 & 27,33 \\
\hline
\end{tabular}

Sumber: Data yang diolah

kerja pemupukan sebesar 9 HOK, pembumbunan $16 \mathrm{HOK}$ dan pengguludan $20 \mathrm{HOK}$. Hasil tersebut merupakan perbandingan kapasitas kerja mekanis terhadap manual dengan 7 jam kerja/hari. Oleh sebab itu, dari sisi teknis kapasitas kerja paket alsintan perawatan tebu dapat menjadi solusi dari permasalahan kelangkaan tenaga kerja manual. Hal ini sesuai dengan penelitian di India menurut (Singh dkk., 2011) mekanisasi perkebunan tebu bertujuan mengurangi perbudakan manusia, meningkatkan produksi, serta meningkatkan efisiensi biaya dan waktu.

Paket alsintan pemupukan, bumbu, dan gulud juga perlu mempertimbangkan hasil kinerja penggunaannya terhadap pertumbuhan tanaman tebu. Keragaan agronomis tebu yang dibudidayakan secara mekanis menjadi tolak ukur untuk menilai kelayakan alsintan tersebut. Keragaan agronomis yang dimaksud adalah perkecambahan, jumlah batang, jumlah rumpun, tinggi batang, dan diameter batang tebu sampai dengan umur 6 bulan. Hasil pengamatan keragaan agronomis di Kebun Comal dan Kebun Pasuruan tersaji pada Tabel 4. Sumber: Data yang diolah

Tabel 4 menunjukkan bahwa pada kedua lokasi, sampai dengan tebu umur 6 bulan parameter perkecambahan, jumlah rumpun dan jumlah batang menunjukkan hasil mekanis hampir sama dengan perlakuan secara manual di kedua lokasi. Tinggi

Tabel 3. Perbandingan kapasitas kerja mekanis dan manual perawatan tebu

\begin{tabular}{|c|c|c|c|c|c|c|c|c|}
\hline \multirow[t]{3}{*}{ Pekerjaan } & \multirow[t]{3}{*}{ Alsintan } & \multicolumn{3}{|c|}{ Kebun Pasuruan } & \multicolumn{3}{|c|}{ Kebun Comal } & \multirow[t]{3}{*}{ Keterangan } \\
\hline & & \multicolumn{2}{|c|}{ Kapasitas kerja } & \multirow{2}{*}{$\begin{array}{l}\text { Rasio } \\
\text { (HOK) }\end{array}$} & \multicolumn{2}{|c|}{ Kapasitas kerja } & \multirow{2}{*}{$\begin{array}{l}\text { Rasio } \\
\text { (HOK) }\end{array}$} & \\
\hline & & $\begin{array}{l}\text { Mekanis } \\
\text { (ha/hari) }\end{array}$ & $\begin{array}{c}\text { Manual } \\
\text { (ha/hari) }\end{array}$ & & $\begin{array}{l}\text { Mekanis } \\
\text { (ha/hari) }\end{array}$ & $\begin{array}{c}\text { Manual } \\
\text { (ha/hari) }\end{array}$ & & \\
\hline Pupuk I & Aplikator pupuk & 0,89 & 0,15 & 6 & 1,05 & 0,12 & 9 & \\
\hline Pupuk II & & 0,89 & 0,15 & 6 & 1,05 & 0,12 & 9 & \\
\hline Bumbun I & Alat bumbun & 1,05 & 0,086 & 12 & 0,93 & 0,06 & 16 & \\
\hline Bumbun II & & & 0,086 & - & & 0,06 & - & $\begin{array}{l}\text { Mekanis tidak } \\
\text { ada kegiatan } \\
\text { bumbun II }\end{array}$ \\
\hline Gulud/impun & Alat impun & 1 & 0,05 & 20 & 0,84 & 0,043 & 20 & \\
\hline
\end{tabular}

Sumber: Data yang diolah 
dan diameter batang di Pasuruan perlakuan manual lebih tinggi dibandingkan perlakuan mekanis. Hal ini merupakan data error yang disebabkan pada saat umur 5 bulan plot manual di Pasuruan tercurah limpasan air dari saluran irigasi selama 1 minggu, sehingga terjadi perbedaan lengas antara plot mekanis dan manual. Selain itu, perbedaan tipologi tanah atau sifat fisik tanah. Tanah di Comal teksturnya lebih berlempung sehingga pengolahannya lebih berat.

Pada uji t-statistik, kedua perlakuan tersebut tidak menunjukkan perbedaan yang signifikan antara kelima keragaan agronomis kecuali pada tinggi dan diameter batang di Pasuruan. Karena kesalahan data akibat force majure. Tabel 5 menunjukkan bahwa secara agronomis penggunaan alsintan sama baiknya dengan manual, bahkan secara teknis lebih efektif menggantikan tenaga kerja manual yang saat ini dirasa mulai langka.

Tabel 5. Analisa statistik uji-t

\begin{tabular}{lll}
\hline \multirow{2}{*}{ Keragaan agronomis } & \multicolumn{2}{l}{ t statistik } \\
\cline { 2 - 3 } & Comal & Pasuruan \\
\hline Perkecambahan $(\%)$ & $-0,028^{\mathrm{ns}}$ & $0,536^{\mathrm{ns}}$ \\
Jumlah batang & $0,731^{\mathrm{ns}}$ & $0,11^{\mathrm{ns}}$ \\
Jumlah rumpun & $0,665^{\mathrm{ns}}$ & $0,041^{\mathrm{ns}}$ \\
Tinggi batang $(\mathrm{cm})$ & $0,548^{\mathrm{ns}}$ & $-3,612$ \\
Diameter batang $(\mathrm{mm})$ & $-1,704^{\mathrm{ns}}$ & $-3,535$ \\
\hline
\end{tabular}

Sumber: Data yang diolah

Keterangan: ns : tidak berbeda nyata, pada taraf 0,05

Pada penelitian ini biaya kerja alsintan yang digunakan dianalisa sehingga dapat diketahui tingkat efisiensi biaya. Pada Tabel 6 tersaji hasil analisa biaya paket alsintan serta tenaga kerja manual pada kegiatan pemupukan, pembumbunan dan pengguludan di Kebun Comal.
Biaya aplikasi pupuk dengan alsintan lebih tinggi jika dibandingkan dengan pekerjaan serupa menggunakan tenaga manual. Hal ini dikarenakan pada pekerjaan mekanis, implemen dirancang sekaligus untuk menutup alur pupuk, sedangkan aplikasi pupuk secara manual cenderung hanya menaburkan pupuk. Oleh sebab itu, jumlah HOK yang diperlukan hanya 2,5 HOK jika dibandingkan dengan mekanis yang setara dengan 6 HOK. Aplikasi pupuk secara manual yang hanya cenderung menaburkan pupuk tanpa menutup dengan tanah tampaknya merupakan kebiasaan yang terjadi di tingkat aplikasi lapang. Di lain pihak, alsintan untuk pupuk melakukan pekerjaan pemupukan dengan membuka alur pupuk, menabur pupuk serta menutup kembali alur pupuk.

Kegiatan bumbun dengan alsintan dapat dilakukan satu kali. Karena jumlah bumbunan tanah telah cukup tinggi $(14 \mathrm{~cm})$ dan menutupi zona perakaran rumpun tebu sehingga lebih efisien dibanding manual yang harus dua kali bumbun untuk mendapatkan bumbunan setinggi $14 \mathrm{~cm}$. Gulud/impun dengan alsintan jauh lebih murah dibanding manual karena pekerjaan mengimpun alur tanam dengan guludan tanah yang lebih banyak dibanding bumbum sehingga dibutuhkan jumlah tenaga lebih banyak. Jumlah biaya kegiatan pupuk, bumbun dan gulud secara mekanis adalah sebesar Rp. 535.528,- sedangkan dengan tenaga manual sebesar Rp. 990.000,-. Maka penggunaan alsintan untuk kegiatan perawatan tebu di Kebun Comal memiliki efisiensi sebesar 45,91\%. Hal ini disebabkan hasil kerja dengan ketiga alsintan lebih baik serta pada kegiatan bumbun mekanis dilakukan sekali setara dengan dua kali bumbun manual. Dengan demikian kinerja ketiga alat mesin ini dapat menggantikan peran tenaga manual setara $22 \mathrm{HOK}$.

Kegiatan perawatan tebu di Kebun Pasuruan yang dilakukan secara mekanis adalah pemupukan, bumbun

Tabel 6 . Perbandingan biaya kerja alsintan dengan manual di Kebun Comal

\begin{tabular}{|c|c|c|c|c|c|c|c|}
\hline \multirow[t]{2}{*}{ Pekerjaan } & \multicolumn{4}{|c|}{ Mekanis } & \multicolumn{2}{|c|}{ Manual } & \multirow{2}{*}{$\begin{array}{c}\text { Efisiensi mekanis } \\
\text { terhadap manual } \\
(\%)\end{array}$} \\
\hline & $\begin{array}{c}\text { Upah operator } \\
\text { (Rp/0,3ha) }\end{array}$ & $\begin{array}{c}\text { Sewa alsintan } \\
(\mathrm{Rp} / 0,3 \mathrm{ha})\end{array}$ & $\begin{array}{c}\text { Biaya } \\
\text { solar (Rp) }\end{array}$ & $\begin{array}{c}\text { Jumlah } \\
\text { (Rp/0,3ha) }\end{array}$ & $\begin{array}{c}\text { Jumlah tenaga } \\
(\mathrm{HOK} / 0,3 \mathrm{ha})\end{array}$ & $\begin{array}{l}\text { Upah tenaga } \\
\text { (Rp/0,3ha) }\end{array}$ & \\
\hline Pupuk I & 74.286 & 42.857 & 15.910 & 133.053 & 2,5 & 112.500 & $(18,27)$ \\
\hline Pupuk II & 74.286 & 42.857 & 11.470 & 128.613 & 2,5 & 112.500 & $(14,32)$ \\
\hline Bumbun I & 66.129 & 48.387 & 14.060 & 128.576 & 5 & 225.000 & 42,86 \\
\hline Bumbun II & & & & & 5 & 225.000 & 100,00 \\
\hline $\begin{array}{l}\text { Gulud/ } \\
\text { impun }\end{array}$ & 73.214 & 53.571 & 18.500 & 145.286 & 7 & 315.000 & 53,88 \\
\hline Jumlah & & & & 535.528 & 22 & 990.000 & 45,91 \\
\hline
\end{tabular}

Sumber: Data yang diolah

Keterangan: 1 HOK manual di Comal seharga Rp. 45.000,-; sewa alsintan merupakan sewa

traktor tangan dan implemen untuk bekerja 0,3 ha selama 3 jam. 
Tabel 7. Perbandingan biaya kerja alsintan dengan manual di Kebun Pasuruan

\begin{tabular}{|c|c|c|c|c|c|c|c|}
\hline \multirow[b]{2}{*}{ Pekerjaan } & \multicolumn{4}{|c|}{ Mekanis } & \multicolumn{2}{|c|}{ Manual } & \multirow[b]{2}{*}{$\begin{array}{c}\text { Efisiensi mekanis } \\
\text { terhadap manual } \\
(\%)\end{array}$} \\
\hline & $\begin{array}{l}\text { Upah operator } \\
\text { (Rp/0,3ha) }\end{array}$ & $\begin{array}{c}\text { Sewa alsintan } \\
(\mathrm{Rp} / 0,3 \mathrm{ha})\end{array}$ & $\begin{array}{c}\text { Biaya solar } \\
\text { (Rp) }\end{array}$ & $\begin{array}{c}\text { Jumlah } \\
\text { (Rp/0,3ha) }\end{array}$ & $\begin{array}{c}\text { Jumlah tenaga } \\
(\mathrm{HOK} / 0,3 \mathrm{ha})\end{array}$ & $\begin{array}{c}\text { Upah tenaga } \\
\text { (Rp/0,3ha) }\end{array}$ & \\
\hline Pupuk I & 75.843 & 50.562 & 12.210 & 138.614 & 2 & 80.000 & $(73)$ \\
\hline Pupuk II & 75.843 & 50.562 & 12.210 & 138.614 & 2 & 80.000 & (73) \\
\hline Bumbun I & 42.857 & 42.857 & 14.800 & 100.514 & 3 & 120.000 & 16 \\
\hline Bumbun II & & & - & & 4 & 160.000 & 100 \\
\hline $\begin{array}{l}\text { Gulud/ } \\
\text { impun }\end{array}$ & 67.500 & 45.000 & 18.500 & 131.000 & 6 & 240.000 & 45 \\
\hline Jumlah & & & & 508.743 & 17 & 680.000 & 25,18 \\
\hline
\end{tabular}

Sumber: Data yang diolah

Keterangan: 1 HOK manual di Pasuruan seharga Rp. 40.000,-; sewa alsintan

merupakan sewa traktor tangan dan implemen untuk bekerja 0,3 ha

dan gulud, perbandingan biaya tersaji pada Tabel 7 . Informasi biaya dari masing-masing kegiatan budidaya menjadi pertimbangan dalam memilih tenaga manual atau mekanis.

Penggunaan tenaga manual secara keseluruhan pada kegiatan budidaya tebu tersebut menghabiskan biaya sejumlah Rp. $680.000,-/ 0,3$ ha. Dengan demikian penggunaan paket alsintan di Kebun Pasuruan 25,18\% lebih efisien dibandingkan secara manual dan pada kedua penggunaan alsintan 35,54\% lebih efektif dibandingkan manual.

Hasil penelitian merupakan temuan baru yang memperkuat pengelolaan agroteknis paket alsintan untuk perawatan tebu yang menjadi solusi dari permasalahan kelangkaan tenaga kerja manual. Keragaan agronomis pada kelima parameter di kedua lokasi dan memperhatikan analisa statistik tidak menunjukkan perbedaan yang nyata, maka hasil sampai dengan tebu 6 bulan antara mekanis dengan manual sama baiknya. Namun demikian, penggunaan paket alsintan menunjukkan biaya lebih rendah dibanding manual. Dengan demikian, hasil ini dapat digunakan sebagai acuan pengembangan mekanisasi pada lahan dengan petakan sempit oleh Pemerintah dan stakeholder pergulaan nasional.

\section{KESIMPULAN}

Pada penelitian ini dapat disimpulkan bahwa secara agroteknis dengan t-test taraf 0,05 menunjukkan dari parameter yang diamati yaitu perkecambahan, jumlah batang, rumpun, tinggi tebu dan diameter batang tidak terdapat beda nyata. Penggunaan paket alsintan pemupukan, bumbun dan gulud di Pasuruan mampu menggantikan tenaga kerja manual $6 \mathrm{HOK}, 12 \mathrm{HOK}$ dan 20 HOK pada setiap kegiatan budidaya tebu dengan traktor bekerja 7 jam/hari. Sedangkan di Comal alsintan dengan spesifikasi seperti yang digunakan dalam kajian ini mampu mensubstitusi tenaga kerja pemupukan 9 HOK, pembumbunan $16 \mathrm{HOK}$, pengguludan $20 \mathrm{HOK}$. Hasil analisis biaya alsintan 35,54\% lebih rendah bandingkan secara manual. Kesimpulan dari penelitian ini paket alsintan mampu menggantikan tenaga kerja manual pada kegiatan perawatan.

\section{UCAPAN TERIMA KASIH}

Ucapan terima kasih kami sampaikan kepada Badan Penelitian dan Pengembangan Pertanian Kementerian Pertanian yang telah memberikan dana untuk melaksanakan penelitian ini. Kami juga mengucapkan terimakasih kepada Direktur Pusat Penelitian Perkebunan Gula Indonesia (P3GI) yang telah memberikan kesempatan kepada penulis untuk melaksanakan penelitian ini di Kebun Percobaan P3GI. Penulis juga mengucapkan terimakasih kepada Prof. Dr. Rosichon Ubaidillah, M.Phill., dari Puslit Biologi LIPI sebagai pembimbing penulisan KTI serta tim peneliti dan teknisi yang telah mendukung dan membantu sehingga penelitian dapat terlaksana dengan lancar dan memberikan hasil yang diharapkan.

\section{DAFTAR PUSTAKA}

Ahmed, E., Adam, Amna O. M. Alam-Eldin, (2015). "An assessment of mechanical vs manual harvesting of the sugarcane in Sudan - The case of Sennar Sugar Factory". Journal of the Saudi Society of Agricultural Sciences. Volume 14, Issue 2, June 2015, Pages 160-166

Ditjenbun. (2015). Kebijakan Pergulaan Nasional, Bahan FGD di P3GI Pasuruan pada 12 Februari 2015. Jakarta: Ditjenbun. 
Ekoprianto, E. 1985. Pengaruh Kerebahan terhadap Kapasitas Lapang dan Biaya Operasi Mesin Panen Tebu. Skripsi Fateta IPB, Bogor.

Kartohadikoesoemo, N. (1965). Penyelenggaraan Tanaman Tebu secara Mekanis. Majalah Perkebunan Gula 1 (1): 46-60.

NgCheong, L. R., K.F. NgKeeKwong, C.C. Du Preez, (2009). "Soil Compaction Under Sugar Cane (Saccharum hybrid sp.) Cropping and Mechanization in Mauritius". South African Journal of Plant and Soil. Volume 26, 2009-Issue 4.

P3GI, (2014). Penguatan Daya Saing Agro Industri Gula Berbasis Tebu untuk Menghadapi Perubahan Lingkungan Strategis. Proposal Pengembangan Pusat Unggulan Iptek Gula. P3GI. Pasuruan, Indonesia.

P3GI, (2015). Kajian Agroteknis Dan Ekonomi Pada Penggunaan Paket Alsintan Untuk Budidaya Tebu Di Lahan Dengan Petakan Sempit. Laporan Hasil Kegiatan. P3GI. Pasuruan, Indonesia.
Pramudya, B. (1989). Permodelan Pada Sistem Perencanaan Mekanisasi Dalam Kegiatan Pemanenan Tebu Untuk Industri Gula. Disertasi Fakultas Pasca Sarjana IPB, Bogor.

Rachmat, Muchjidin, (1992). Kesempatan Kerja Dan Prospek Ketenagakerjaan Dalam Pengembangan Tebu Di Jawa. Forum Penelitian Agro Ekonomi. PSEKP, Balitbang Kementan. Vol 9, No 2-1 (1992).

Singh, Jaswant, A.K. Singh, M.P. Sharma, P.R. Singh, A.C. Srivasta. (2011). Mechanization of Sugarcane Cultivation in India. SugarTech December 2011, Volume 13, Issue 4, pp 310-314.

Syafrindi, Lubis, A., \& Siregar, K. (2015). Desain Alat Kepras Tebu dengan Tenaga Hand Traktor untuk Meningkatkan Mutu Tebu Keprasan. Prosiding Seminar Agroindustri dan Lokakarya Nasional FKPT-TPI. UTM, Aceh. 